\title{
Do the application forms and doses of boron affect wheat crops?
}

\author{
Fernando S. Galindo ${ }^{1}$, Marcelo C. M. Teixeira Filho' ${ }^{1}$, Salatiér Buzetti ${ }^{1}$, \\ Eduardo H. M. Boleta ${ }^{1}$, Willian L. Rodrigues ${ }^{1} \&$ Alexandre R. M. Rosa $^{1}$
}

\begin{abstract}
${ }^{1}$ Universidade Estadual Paulista "Júlio de Mesquita Filho"/Faculdade de Engenharia de Ilha Solteira/Departamento de Fitossanidade, Engenharia Rural e Solos. Ilha Solteira, SP. E-mail: fs.galindo@yahoo.com.br (Corresponding author) - ORCID: 0000-0001-5118-7459; mcmtf@yahoo.com.br - ORCID: 0000-0003-2303-3465; sbuzetti@agr.feis.unesp.br - ORCID: 0000-0003-2569-4750; eduardomarcandalli7@gmail.com - ORCID: 0000-0001-7969-8197; willianrodrigues53@gmail.com - ORCID: 0000-0002-3826-5915; alexandrematheusrosa@gmail.com - ORCID: 0000-0002-2375-9111
\end{abstract}

\section{Key words:}

Triticum aestivum

borated fertilization

boron time application

boron concentration in aerial part grain yield

\begin{abstract}
A B S T R A C T
Boron is one of the most limiting micronutrients in the grain production system in Brazil. Thus, the objective of this study was to evaluate the effects of the application forms and doses of boron on the concentration of this nutrient in the leaves, straw, and grains of wheat, as well as the production components and grain yield. The residual effect of boron in the soil was also evaluated. An experiment was conducted in a no-tillage system in Oxisol with clay texture in Selvíria, Mato Grosso do Sul. The experimental design was a randomized block design with four replicates arranged in a $4 \times 3$ factorial scheme. Four doses of boron $(0$, 1,2 , and $\left.4 \mathrm{~kg} \mathrm{ha}^{-1}\right)$ were applied with a boric acid source $(\mathrm{B}=17 \%)$ and three application forms: a) during the desiccation of the predecessor straw with herbicide; b) at the time of sowing in soil along with formulated fertilization seeding, and c) via the leaves with the application of post-emergent herbicide. The application of boron to the soil at the time of sowing at an approximate dose of $2 \mathrm{~kg} \mathrm{ha}^{-1}$ provides the highest number of spikelets per ear and wheat grain yield.
\end{abstract}

\section{Palavras-chave:}

Triticum aestivum

adubação boratada

momento da aplicação de boro concentração de boro em parte aérea produtividade de grãos

\section{As formas de aplicação e as doses de boro afetam a cultura do trigo?}

\section{R E S U M O}

O boro é um dos micronutrientes que mais limita a produtividade de grãos do sistema produtivo no Brasil. Desta forma, objetivou-se avaliar o efeito de formas de aplicação e doses de boro na concentração deste nutriente na folha diagnose, palhada e grãos de trigo, componentes produtivos e produtividade de grãos, bem como o efeito residual de B no solo. O experimento foi realizado em Selvíria, MS, em sistema plantio direto em um Latossolo Vermelho distrófico, textura argilosa. O delineamento experimental foi em blocos ao acaso com quatro repetições, dispostas em esquema fatorial $4 \times 3$, com quatro doses de boro (0, 1, 2 e $\left.4 \mathrm{~kg} \mathrm{ha}^{-1}\right)$ na forma de ácido bórico $(\mathrm{B}=17 \%)$; e três formas de aplicação: a) na dessecação da palhada antecessora, juntamente com o herbicida; b) no momento da semeadura, no solo juntamente com a adubação de semeadura e c) via foliar, junto com a aplicação do herbicida pós-emergente. A aplicação de B ao solo no momento da semeadura na dose aproximada de $2 \mathrm{~kg} \mathrm{ha}^{-1}$ propiciou o maior número de espiguetas por espiga e produtividade de grãos de trigo. 


\section{INTRODUCTION}

Wheat (Triticum aestivum L.) is an annual cycle plant and a type of cool-season cereal. Wheat has great economic importance and large grain yield capacity (Teixeira Filho et al., 2010, 2012, 2014; Marini et al., 2011; Theago et al., 2014). This cereal occupies over $17 \%$ of cultivable land in the world and represents approximately $30 \%$ of world grain production. From 2012 to 2016, the annual average area of wheat cultivated worldwide was approximately 220 million hectares, with the harvest reaching 734 million tons in 2015 and 2016 (USDA, 2016).

Fertilization is one of the factors that favors the productivity and sustainability of the activity (Araújo, 2011; Galindo et al., $2016,2017 \mathrm{a}, \mathrm{b})$. Boron (B) is one of the nutrients that have the greatest effect on productivity and is the most limiting micronutrient for crops. This is especially the case in tropical soils, which are generally low in available B and organic matter, which is a major source of this nutrient for plants. These conditions culminate in inadequate plant nutrition (Souza et al., 2011).

Boron is an essential element for plant growth and participates in several processes, such as sugar transport, lignification, cell wall structure, carbohydrate metabolism, RNA metabolism, respiration, indole acetic acid (IAA) metabolism, phenolic metabolism, and ascorbate metabolism. It also has functions in cell wall synthesis and plasma membrane integrity (Calonego et al., 2010; Foloni et al., 2016). According to Metwally et al. (2017), B influences the germination of pollen grains and pollen tube growth, increases flower glue and granulation, and causes less male sterility and less grain puffiness. In addition to the better fertilization of flowers and grain formation, B interferes with the retention of newly formed spikes and acts on meristem growth, cell differentiation, maturation, cell division, and plant growth (Tahir et al., 2009; Muhmood et al., 2014).

As a result of its low mobility within the phloem, there is a need for constant availability or supply of this nutrient during the vegetative phase of plants (Calonego et al., 2010; Mantovani et al., 2013). Thus, more studies are needed on the ideal management of borated fertilization. However, there are few studies on B fertilization in wheat cultivation focusing on the best application method associated with the appropriate dose of this nutrient. Therefore, the objective of this study was to evaluate the application forms and doses of $\mathrm{B}$ on the concentration of this nutrient in the leaves, straw, and grains of wheat, the production components, grain yield, and the residual effects of $\mathrm{B}$ in the soil.

\section{Material ANd Methods}

This research was conducted in 2016 at an experimental station located in Selvíria, Mato Grosso do Sul $\left(20^{\circ} 22^{\prime} \mathrm{S}, 51^{\circ}\right.$ $22^{\prime} \mathrm{W}$, altitude of $335 \mathrm{~m}$ ), Brazil. The average temperature was $23.5^{\circ} \mathrm{C}$, the annual average precipitation was $1,370 \mathrm{~mm}$, and the annual average relative humidity was $70-80 \%$ (Figure 1 ). The soil in the experimental area was classified as Oxisol (Latossolo Vermelho distrófico) with clayey texture (EMBRAPA, 2013).

The chemical attributes of the soil at depths of $0-0.20$ and 0.20-0.40 m were determined in 2016 before beginning the experiment using the methodology proposed by Raij et al. (2001). The following results were obtained at $0-0.20 \mathrm{~m}$ : $19 \mathrm{mg} \mathrm{dm}^{-3} \mathrm{P}$ (resin); $10 \mathrm{mg} \mathrm{dm}{ }^{-3}$ of S-SO $; 21 \mathrm{~g} \mathrm{dm}^{-3}$ organic matter; $5.0 \mathrm{pH}\left(\mathrm{CaCl}_{2}\right)$; $\mathrm{K}, \mathrm{Ca}, \mathrm{Mg}, \mathrm{H}+\mathrm{Al}$, and $\mathrm{Al}=2.1,19.0$, 13.0, 28.0, and $1.0 \mathrm{mmol}_{\mathrm{c}} \mathrm{dm}^{-3}$, respectively; $\mathrm{Cu}, \mathrm{Fe}, \mathrm{Mn}, \mathrm{Zn}$ $(\mathrm{DTPA})=3.1,20.0,27.2$, and $0.8 \mathrm{mg} \mathrm{dm}^{-3}$, respectively; $0.17 \mathrm{mg} \mathrm{dm}^{-3} \mathrm{~B}$ (hot water) and $55 \%$ base saturation. The following results were obtained at $0.20-0.40 \mathrm{~m}: 17 \mathrm{mg} \mathrm{dm}^{-3} \mathrm{P}$ (resin); $30 \mathrm{mg} \mathrm{dm}^{-3}$ of S-SO $; 16 \mathrm{~g} \mathrm{dm}^{-3}$ organic matter; $4.8 \mathrm{pH}$ $\left(\mathrm{CaCl}_{2}\right) ; \mathrm{K}, \mathrm{Ca}, \mathrm{Mg}, \mathrm{H}+\mathrm{Al}$, and $\mathrm{Al}=1.2,11.0,8.0,28.0$, and $2.0 \mathrm{mmol}_{\mathrm{c}} \mathrm{dm}^{-3}$, respectively; $\mathrm{Cu}, \mathrm{Fe}, \mathrm{Mn}, \mathrm{Zn}(\mathrm{DTPA})=2.1$, $10.0,10.7$, and $0.2 \mathrm{mg} \mathrm{dm}^{-3}$, respectively; $0.11 \mathrm{mg} \mathrm{dm}^{-3} \mathrm{~B}$ (hot water) and $42 \%$ base saturation.

The granulometric analysis at these depths presented the following results: 433,471 , and $90 \mathrm{~g} \mathrm{~kg}^{-1}$ of clay, sand, and silt at

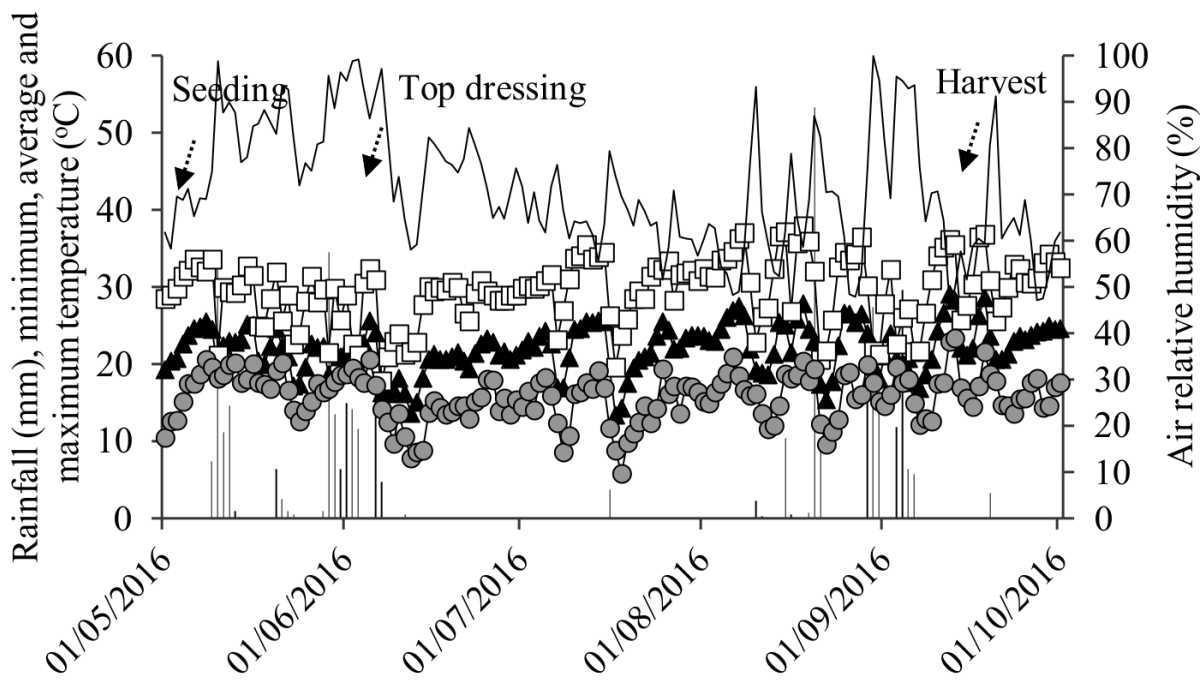

Figure 1. Rainfall, air relative humidity, and maximum, average, and minimum temperatures obtained from the weather station located on the Education and Research Farm of FE / UNESP during wheat cultivation in the period of May to October 2016 
0-0.20 $\mathrm{m}$ and 447,471 , and $82 \mathrm{~g} \mathrm{~kg}^{-1}$ at $0.20-0.40 \mathrm{~m}$, respectively. The experimental area has been cultivated with annual crops for more than 27 years, and the no-tillage system has been used for the past 10 years with corn as a predecessor crop. Corn straw was collected to estimate the accumulation of nutrients: 62.3, $11.5,45,44.5,17.8$, and $15.8 \mathrm{~kg} \mathrm{ha}^{-1}$ of $\mathrm{N}, \mathrm{P}, \mathrm{K}, \mathrm{Ca}, \mathrm{Mg}$ and $\mathrm{S}$, respectively, and 217.9, 178.1, 1940.9, 1210.8, and $267.1 \mathrm{~g} \mathrm{ha}^{-1}$ of $\mathrm{B}, \mathrm{Cu}, \mathrm{Fe}, \mathrm{Mn}$, and $\mathrm{Zn}$, respectively.

The statistical design was randomized blocks with four replications and a $4 \times 3$ factorial design. Four boron doses $\left(0,1,2\right.$ and $\left.4 \mathrm{~kg} \mathrm{ha}^{-1}\right)$ were applied with a boric acid source $(\mathrm{B}=17 \%)$ and three application forms: a) during desiccation of the predecessor straw together with herbicide ( 2 weeks before wheat sowing); b) at the time of sowing in soil along with formulated fertilization seeding, and c) via the leaves with the application of post-emergent herbicide (20 days after emergence). The experimental plots were composed of 12 lines with lengths of $5 \mathrm{~m}$ and spaced at a distance of $0.17 \mathrm{~m}$. The useful area of the plot considered was the central eight lines with the exclusion of $0.5 \mathrm{~m}$ from the ends.

The herbicides used in the experimental areas were glyphosate (1800 $\mathrm{g} \mathrm{ha}^{-1}$ of a.i.) and 2,4-D (670 $\mathrm{g} \mathrm{ha}^{-1}$ of a.i.) for desiccation. The products were applied two weeks before wheat cultivation. Based on the results of soil analysis and the need to increase the base saturation to $70 \%, 1.2 \mathrm{t} \mathrm{ha}^{-1}$ of dolomitic limestone $(\mathrm{PRNT}=80 \% \mathrm{CaO}=28 \%$ and $\mathrm{MgO}=20 \%)$ were applied to the soil 60 days before sowing wheat in 2016, as recommended by Cantarella et al. (1997). Furthermore, based on the results of the soil analysis and crop requirements, $275 \mathrm{~kg} \mathrm{ha}^{-1}$ of 8-28-16 formula were supplied for sowing fertilization. For seed treatment, the fungicides carbendazim + thiram $(45 \mathrm{~g}+105 \mathrm{~g}$ of a.i. per $100 \mathrm{~kg}$ of seed) and the insecticides imidacloprid + thiodicarb $(45 \mathrm{~g}+135 \mathrm{~g}$ of a.i. per $100 \mathrm{~kg}$ of seed) were used.

The wheat crop was irrigated using a center pivot sprinkling system with a mean water depth of $14 \mathrm{~mm}$ and an irrigation interval of approximately $72 \mathrm{~h}$. The cultivar used was CD 1104 with mechanical seeding on May 3, 2016, at a density of 70 seeds per meter. The seedlings emerged 5 days after sowing on May 8, 2016.

Weeds were managed with the application of the herbicide metsulfuron-methyl ( $3 \mathrm{~g} \mathrm{ha}^{-1}$ of a.i.) at 20 days after emergence (DAE) of wheat. Nitrogen fertilization was performed manually on June 8,2016 , with 30 DAE using urea as a source $(45 \%$ $\mathrm{N})$. The fertilizer was spread on the soil surface without incorporation on the sides and at approximately $8 \mathrm{~cm}$ from the sowing lines to avoid contact of the plants with the fertilizer at a dose of $140 \mathrm{~kg} \mathrm{ha}^{-1}$ of $\mathrm{N}$. After cover fertilization, the area was irrigated by sprinkling (depth of $14 \mathrm{~mm}$ ) at night to minimize losses by volatilization of ammonia, which is common in irrigated wheat. The plants in the useful area of the plot were harvested manually at $120 \mathrm{DAE}$ on September 8, 2016.

The plant height at maturity was determined and defined as the distance $(\mathrm{m})$ from the ground level to the apex of the spike. The following characteristics were also evaluated in 10 spikes at harvest: spike length from the apex to the base of the spike; number of spikelets (all spikelets with grains); number of grains per spike (the number of grains in each spike); grains per spiketet (the number of grains in each spike divided by the number of spikelets), and the number of defective grains (the number of undeveloped spikelets per spike).

The B concentration in the leaves, straw, and grains was determined according to the methodology proposed by Malavolta et al. (1997). First, 20 flag leaves were collected at full flowering of the wheat plants from each plot according to methodology described by Cantarella et al. (1997). Straw and grains were collected at the end of the production cycle after plant collection in three $0.5-\mathrm{m}^{2}$ experimental areas per plot. The B content in soil (depth of $0-0.20 \mathrm{~m}, \mathrm{~B}$ in hot water) was determined after harvest occasion using the methodology proposed by Raij et al. (2001).

The leaf chlorophyll index (LCI) was also measured indirectly in the middle third of the flag leaves of five plants per plot in the flowering period using a digital chlorophyll meter model. The number of spikes per meter was determined by counting the number of spikes at harvest on a 1-m plant row in the useful area of each plot. The hectoliter mass was determined as the mass of wheat grains in $100 \mathrm{~L}$ determined on a $1 / 4$ scale after adjusting the water content of the grains to $13 \%$ (wet basis). The mass of 1000 grains was measured using a 0.01 -g precision scale at $13 \%$ (wet basis). The yield was determined by counting the spikes of plants present in the four useful lines of each plot. After mechanical tracking, the grains were quantified, and the data were converted into $\mathrm{kg} \mathrm{ha}^{-1}$ at $13 \%$ (wet basis). The harvest index (HI) was calculated as a percentage using the following equation: $\mathrm{HI}=$ (grain yield/ grain yield + aerial part yield) x 100 .

The results were subjected to analysis of variance ( $F$ test) and Tukey's test using a level of significance of 0.05 for the comparison of the average yields obtained with different forms of $B$ application. The regression equations were adjusted to the effect of B doses using Sisvar software (Ferreira, 2011).

\section{Results AND Discussion}

$\mathrm{B}$ doses influenced the number of spikelets per spike; the $\mathrm{B}$ concentrations in the leaves, straw, and grains; and the wheat grain yield (Tables 1 and 2). There was an adjustment to the linear function increasing for the concentrations of B in leaf tissue (Figure 2B) and in the grains (Figure 2D). There was also an adjustment to the quadratic function for the number of spikelets per spike (Figure 2A), the B concentration in straw (Figure 2C), and grain yield (Figure 2F). The points of maximum doses were 2.33 and $2.24 \mathrm{~kg} \mathrm{ha}^{-1}$ of B for the number of spikelets per spike and grain yield, respectively. The minimum dose point occurred at $1.59 \mathrm{~kg} \mathrm{ha}^{-1}$ for the B concentration in the straw. These results are due to the deficient $\mathrm{B}$ content in the soil. The $B$ requirement of wheat and the sensitivity of its system root are greater than that of common beans, soybeans, rice, and maize in descending order. This means that wheat requires more B for the development of the system root (Fageria, 2000).

Boron is an essential element for plant growth and participates in several processes, such as sugar transport, lignification, cell wall structure, carbohydrate metabolism, RNA metabolism, respiration, indole acetic acid (IAA) metabolism, phenolic metabolism, and ascorbate metabolism. It also has functions in cell wall synthesis and plasma membrane integrity (Calonego et al., 2010). 
Table 1. Leaf chlorophyll index ( $\mathrm{LCl})$, plant height $(\mathrm{PH})$, number of spikes per meter, spikelets per spike, grains per spikelets, grains per spike and defective grains, spike length, hectoliter mass and mass of 1000 grains (M1000) in function of B doses and forms of application

\begin{tabular}{|c|c|c|c|c|c|c|c|c|c|c|}
\hline $\begin{array}{c}\text { Doses (D) } \\
\left(\mathrm{kg} \mathrm{ha}^{-1}\right)\end{array}$ & LCI & $\begin{array}{l}\mathrm{PH} \\
(\mathrm{cm})\end{array}$ & $\begin{array}{c}\text { Spikes } \\
\text { per meter }\end{array}$ & $\begin{array}{l}\text { Spikelets } \\
\text { per spike }\end{array}$ & $\begin{array}{c}\text { Grains } \\
\text { per spikelets }\end{array}$ & $\begin{array}{c}\text { Grains } \\
\text { per spikes }\end{array}$ & $\begin{array}{c}\text { Defective } \\
\text { grains }\end{array}$ & $\begin{array}{l}\text { Spike } \\
\text { length } \\
\text { (cm) }\end{array}$ & $\begin{array}{c}\text { Hectoliter } \\
\text { mass } \\
\left(\mathrm{kg} \mathrm{100L}^{-1}\right)\end{array}$ & $\begin{array}{c}\text { M1000 } \\
\text { (g) }\end{array}$ \\
\hline 0 & 58.56 & 87.76 & 128.89 & 18.47 & 2.28 & 41.77 & 2.03 & 8.08 & 69.68 & 34.10 \\
\hline 1 & 60.30 & 88.93 & 124.44 & 19.01 & 2.24 & 41.54 & 1.99 & 7.89 & 70.92 & 38.40 \\
\hline 2 & 58.23 & 88.30 & 139.33 & 20.08 & 2.12 & 41.53 & 2.17 & 8.02 & 71.23 & 36.40 \\
\hline 4 & 60.34 & 86.48 & 125.33 & 19.02 & 2.18 & 39.66 & 1.99 & 7.32 & 71.15 & 37.80 \\
\hline \multicolumn{11}{|l|}{ Forms (F) } \\
\hline Straw & $59.80 \mathrm{a}$ & $88.64 \mathrm{a}$ & $122.00 \mathrm{a}$ & $19.54 \mathrm{a}$ & $2.20 \mathrm{a}$ & $41.33 \mathrm{a}$ & $2.22 \mathrm{a}$ & $7.95 \mathrm{a}$ & $70.11 \mathrm{a}$ & $35.30 \mathrm{~b}$ \\
\hline Soil & $58.56 \mathrm{a}$ & $87.13 \mathrm{a}$ & $134.50 \mathrm{a}$ & $19.01 \mathrm{a}$ & $2.16 \mathrm{a}$ & $40.30 \mathrm{a}$ & $2.01 \mathrm{a}$ & $7.54 \mathrm{a}$ & $71.04 \mathrm{a}$ & $39.00 \mathrm{a}$ \\
\hline Leaf & $59.71 \mathrm{a}$ & $87.83 \mathrm{a}$ & $132.00 \mathrm{a}$ & $18.88 \mathrm{a}$ & $2.26 \mathrm{a}$ & $41.75 \mathrm{a}$ & $1.90 \mathrm{a}$ & $7.99 a$ & $71.08 \mathrm{a}$ & $35.70 \mathrm{~b}$ \\
\hline L.S.D. (5\%) & 2.11 & 2.00 & 19.50 & 1.08 & 0.15 & 3.14 & 0.63 & 0.98 & 2.76 & 3.30 \\
\hline Overall mean & 59.36 & 87.87 & 129.50 & 19.15 & 2.20 & 41.13 & 2.04 & 7.83 & 70.75 & 36.70 \\
\hline C.V. & 3.47 & 2.22 & 14.68 & 5.51 & 6.47 & 7.45 & 29.25 & 12.24 & 3.80 & 8.87 \\
\hline \multicolumn{11}{|l|}{ F test } \\
\hline D & $1.659^{\text {ns }}$ & $2.549^{\text {ns }}$ & $1.162^{\mathrm{ns}}$ & $7.991^{\star *}$ & $2.178^{\text {ns }}$ & $0.930^{\mathrm{ns}}$ & $0.168^{\text {ns }}$ & $1.190^{\mathrm{ns}}$ & $0.654^{\mathrm{ns}}$ & $1.522^{\text {ns }}$ \\
\hline $\mathrm{F}$ & $7.454^{* \star}$ & $1.804^{\mathrm{ns}}$ & $1.453^{\text {ns }}$ & $1.313^{\text {ns }}$ & $1.461^{\text {ns }}$ & $0.710^{\text {ns }}$ & $0.809^{\text {ns }}$ & $0.825^{\text {ns }}$ & $0.500^{\text {ns }}$ & $4.777^{\star}$ \\
\hline$D \times F$ & $0.521^{\text {ns }}$ & $2.145^{\mathrm{ns}}$ & $1.608^{\text {ns }}$ & $0.562^{\text {ns }}$ & $0.565^{\mathrm{ns}}$ & $2.085^{\mathrm{ns}}$ & $0.788^{\text {ns }}$ & $1.922^{\mathrm{ns}}$ & $0.878^{\text {ns }}$ & $0.545^{\text {ns }}$ \\
\hline
\end{tabular}

Means followed by the same letter in the column do not differ by the Tukey test at 0,01 probability level; ${ }^{* *},{ }^{*}$, ns Significant at $p<0.01, p<0.05$ probability level and not significant, respectively

Table 2. Soil content of B, B concentrations in diagnose leaf, straw and grains, harvest index $(\mathrm{HI})$ and wheat grain yield in function of $B$ doses and forms of application

\begin{tabular}{|c|c|c|c|c|c|c|}
\hline $\begin{array}{c}\text { Doses (D) } \\
\left(\mathrm{kg} \mathrm{ha}^{-1}\right)\end{array}$ & $\begin{array}{c}\text { B soil } \\
\left(\mathrm{mg} \mathrm{dm}^{-3}\right)\end{array}$ & B leaf & $\frac{\text { B straw }}{\left(\mathrm{mg} \mathrm{kg}^{-1} \text { D.M.) }\right.}$ & B grains & $\begin{array}{l}\mathrm{HI} \\
(\%)\end{array}$ & $\begin{array}{c}\text { Grain yield } \\
\left(\mathrm{kg} \mathrm{ha}^{-1}\right)\end{array}$ \\
\hline 0 & 0.28 & 36.59 & 7.97 & 0.67 & 61.61 & 3638.93 \\
\hline 1 & 0.40 & 38.16 & 7.21 & 1.30 & 63.87 & 4094.27 \\
\hline 2 & 0.43 & 39.49 & 7.09 & 0.95 & 63.06 & 4223.36 \\
\hline 4 & 0.75 & 44.56 & 9.19 & 1.61 & 63.49 & 3883.16 \\
\hline \multicolumn{7}{|l|}{ Forms (F) } \\
\hline Straw & 0.48 & $34.08 \mathrm{~b}$ & $7.30 \mathrm{~b}$ & $1.27 \mathrm{a}$ & $61.58 \mathrm{a}$ & $3695.06 \mathrm{~b}$ \\
\hline Soil & 0.43 & $36.84 \mathrm{~b}$ & $7.41 \mathrm{ab}$ & $0.99 a$ & $63.28 \mathrm{a}$ & $4310.86 \mathrm{a}$ \\
\hline Leaf & 0.49 & $48.18 \mathrm{a}$ & $8.89 a$ & $1.15 \mathrm{a}$ & $64.15 \mathrm{a}$ & $3873.88 \mathrm{~b}$ \\
\hline L.S.D. (5\%) & 0.15 & 6.16 & 1.57 & 0.42 & 3.46 & 427.00 \\
\hline Overall mean & 0.46 & 39.70 & 7.87 & 1.13 & 63.01 & 3959.93 \\
\hline C.V. & 23.47 & 15.13 & 19.48 & $22.18^{\#}$ & 4.06 & 10.51 \\
\hline \multicolumn{7}{|l|}{ F test } \\
\hline D & $21.101^{\star \star}$ & $8.715^{\star *}$ & $3.585^{\star}$ & $8.995^{\star *}$ & $0.892^{\text {ns }}$ & $9.390^{\star \star}$ \\
\hline $\mathrm{F}$ & 0.782 ns & $18.550^{\star \star}$ & $4.071^{*}$ & $1.385^{\mathrm{ns}}$ & $2.085^{\mathrm{ns}}$ & $6.952^{\star *}$ \\
\hline$D \times F$ & $14.123^{\star \star}$ & $1.041^{\mathrm{ns}}$ & $1.007^{\mathrm{ns}}$ & $1.106^{\mathrm{ns}}$ & $1.276^{\mathrm{ns}}$ & $1.921^{\text {ns }}$ \\
\hline
\end{tabular}

Means followed by the same letter in the column do not differ by the Tukey test at 0.05 probability level. ${ }^{* *},{ }^{*}$, ns Significant at $p<0.01, p<0.05$ probability level and not significant, respectively. ${ }^{*}$ Corrected data following equation $(x+0.5)^{0.5}$

Furthermore, it influences the germination of the pollen grains and pollen tube growth, increases flower glue and granulation, and causes less male sterility and less grain puffiness (Metwally et al., 2017). In addition to the better fertilization of flowers and grain formation, B interferes in the retention of spikes, besides acting on meristem growth, cell differentiation, maturation, cell division and plant growth (Tahir et al., 2009; Muhmood et al., 2014). The innumerable functions of $B$ increase the number of spikelets per spike. Greater absorption of this nutrient also increases B in the leaves, grains, and aerial parts, which positively influences the grain yield. It is noteworthy that numerically, the approximate dose that resulted in higher grain yield ( $2 \mathrm{~kg} \mathrm{ha}^{-1}$ of B) also resulted in an increase in the number of spikes per meter, hectoliter mass, and mass of 1000 grains compared to the control by 8.1, 2.2, and $6.7 \%$, respectively (Table 1 ).

Souza et al. (2011) obtained similar results when working with $0,0.6,1.2,1.8$, and $2.4 \mathrm{~kg} \mathrm{ha}^{-1}$ of $\mathrm{B}$ in common bean crop. They obtained the maximum grain yield at a $B$ dose of $1.8 \mathrm{~kg} \mathrm{ha}^{-1}$. Muhmood et al. (2014) researched the borate fertilization of wheat and obtained a higher grain yield at a dose of $2 \mathrm{~kg} \mathrm{ha}^{-1}$ and Debnath et al. (2011) found a higher yield of wheat grain at a B dose of $1.9 \mathrm{~kg} \mathrm{ha}^{-1}$. However, Brunes et al. (2015) found that borated fertilization applied at sowing or tillering in doses between 2.5 and $3.0 \mathrm{~kg} \mathrm{ha}^{-1}$ caused an increase in the number of seeds and spikes produced per plant. However, there was a reduction in the seed yield per plant, the mass of 1000 seeds, and the hectoliter mass. This contrasts with the results in the present work, but a drastic reduction in grain yield was observed at B doses above $2.8 \mathrm{~kg} \mathrm{ha}^{-1}$.

Regardless of the dose, the $\mathrm{B}$ concentration in wheat leaves was above the ideal range of $5-20 \mathrm{mg} \mathrm{kg}^{-1} \mathrm{D}$. M. recommended by Cantarella et al. (1997). The mean value was $39.4 \mathrm{mg} \mathrm{kg}^{-1} \mathrm{D}$. M. However, when analyzing the linear increase in $\mathrm{B}$ concentrations in the leaves, grains, and aerial parts, there was a quadratic response in grain yield at does up to $2 \mathrm{~kg} \mathrm{ha}^{-1}$. It is possible that there was abundant consumption of this micronutrient at this dose. Due to the very narrow range between deficiency and toxicity of $\mathrm{B}$, phytotoxicity may have occurred at doses above $3 \mathrm{~kg} \mathrm{ha}^{-1}$ of $\mathrm{B}$, which would have negatively influenced the number of spikelets per spike and the grain yield. 

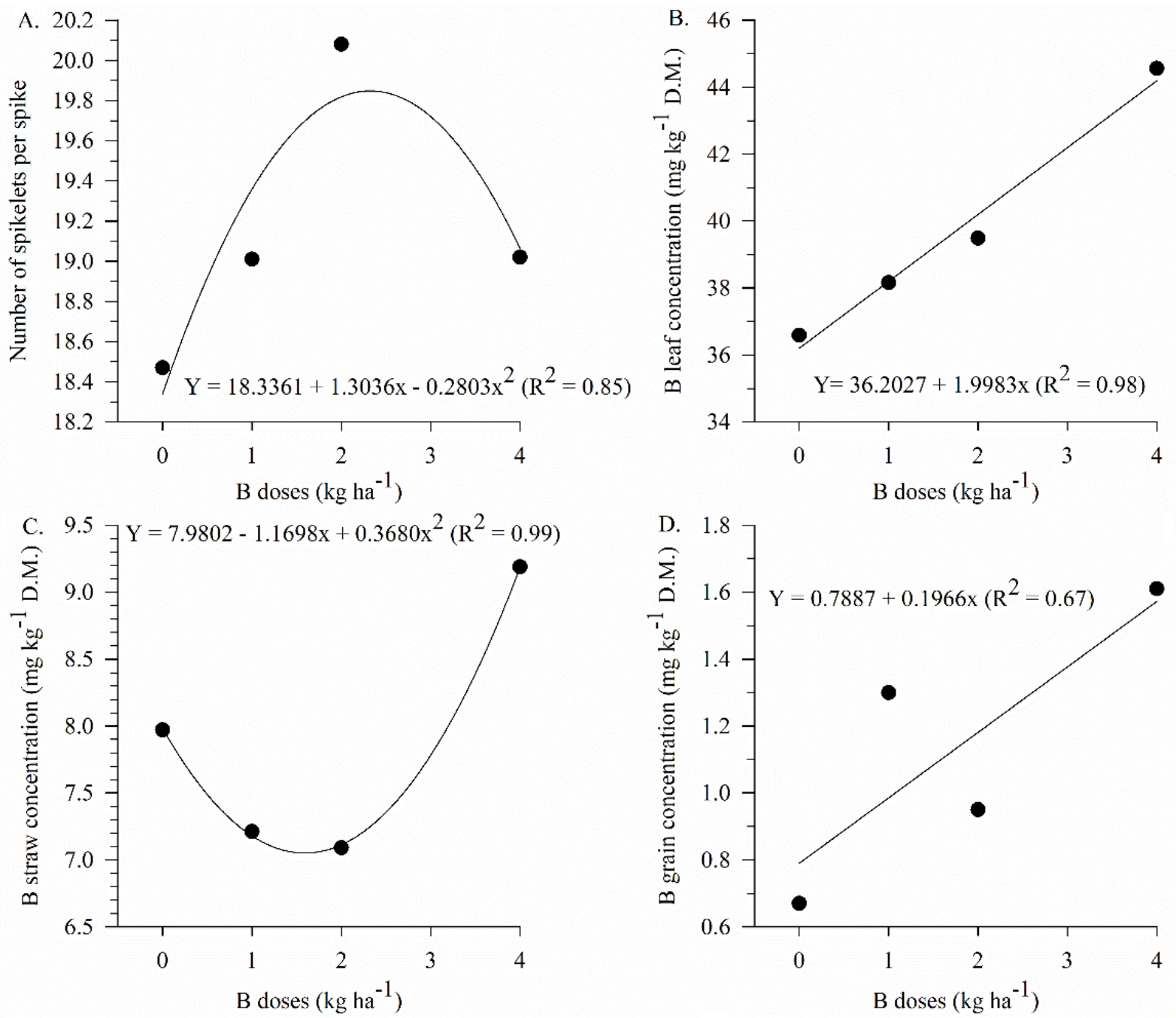

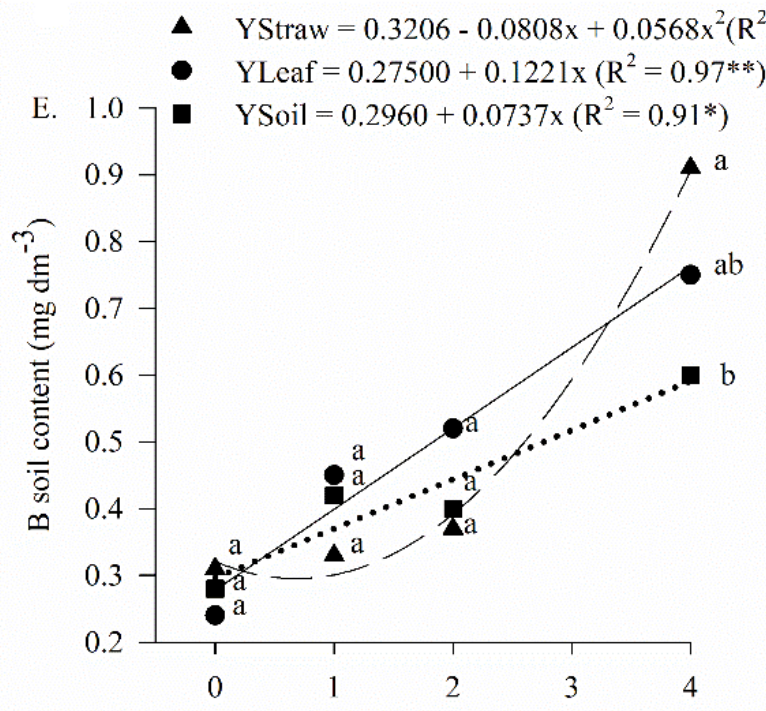

B doses $\left(\mathrm{kg} \mathrm{ha}^{-1}\right)$

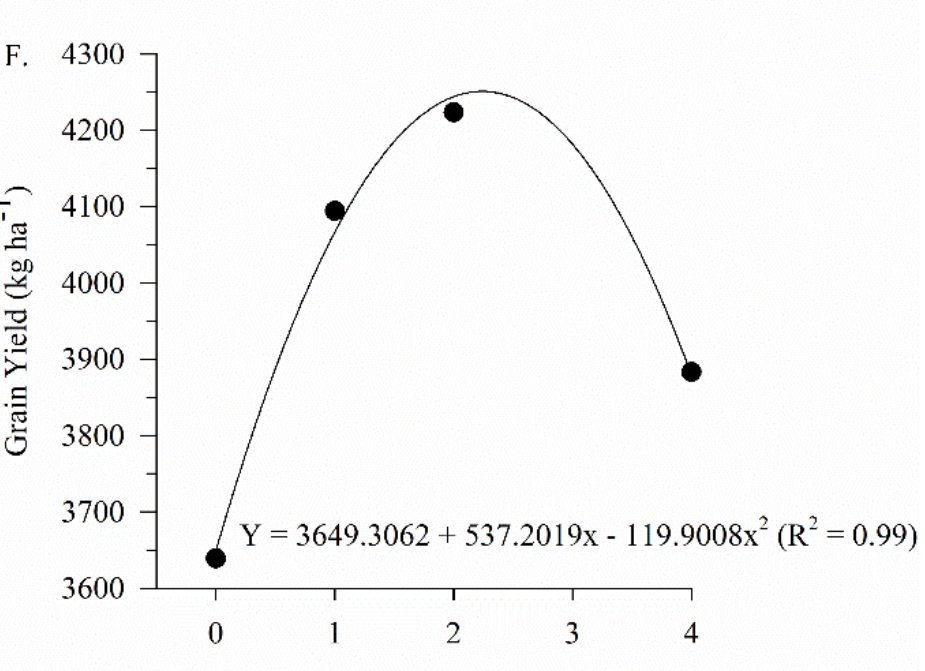

$\mathrm{B}$ doses $\left(\mathrm{kg} \mathrm{ha}^{-1}\right)$

Figure 2. Number of spikelets per spike (A); B leaf concentration (B); B straw concentration (C); B grains concentration (D) and grain yield (E) in function of B doses, and interaction between doses and forms of B application on B soil content (E).

Foliar application provides a higher concentration of $B$ in the leaves compared to application in the predecessor straw and in the soil at the time of sowing (Table 2). Similarly, for the $\mathrm{B}$ concentration in straw, foliar application provided a higher concentration compared to the application in the predecessor straw, which did not differ from soil application (Table 2). This result is explained by the low mobility of $\mathrm{B}$ in the phloem. In the foliar application, the absorbed B is retained in the leaves and aerial parts, which culminates in higher concentrations. 
The application of B in soil at the time of sowing resulted in a greater mass of 1000 grains and grain yield compared to the other forms of application (Tables 1 and 2). In addition, it resulted in a higher number of spikes per meter compared to straw and foliar application (9.3 and 1.9\% higher on average, respectively). Unlike in the aerial parts of the plant, boron in soil shows high mobility due to crop irrigation. Its uptake is favored by transpiratory flow, which is reflected in better use of the nutrient by the wheat and thus better grain yield.

The interaction between doses and application forms of B was significant for only the soil content of B (Table 2). At a B dose of $4 \mathrm{~kg} \mathrm{ha}^{-1}$, the application of this nutrient to the predecessor straw provided a higher content compared to the application in soil, which did not differ from foliar application. The result is lower absorption or leaching of B. There was an adjustment to the increasing linear function for foliar and soil application and an adjustment to the quadratic function for straw application. The maximum content was obtained with the application of $4 \mathrm{~kg} \mathrm{ha}^{-1}$ of B (Figure 2E).

Based on the results, it is recommended that irrigated wheat be fertilized with a B dose of $2 \mathrm{~kg} \mathrm{ha}^{-1}$. This dose favors high grain yield and optimizes the productive system of this crop. This could allow the crop to be grown at a larger scale in the low-altitude Cerrado region.

\section{Conclusions}

1. Increases in $\mathrm{B}$ doses up to $2 \mathrm{~kg} \mathrm{ha}^{-1}$ have a positive influence on the $\mathrm{B}$ concentrations in the soil, leaves, and straw, as well as the number of spikelets per spike, grains, and wheat grain yield. However, there is a negative influence on the $\mathrm{B}$ concentration in straw until $2 \mathrm{~kg} \mathrm{ha}^{-1}$.

2. The application of $B$ via the leaves provides higher concentrations of $B$ in the leaves and straw. However, a greater mass of 1000 grains and grain yield were obtained with $B$ application in the soil.

3. The application of $B$ to the soil at the time of sowing at an approximate dose of $2 \mathrm{~kg} \mathrm{ha}^{-1}$ provides the highest number of spikelets per spike and wheat grain yield.

\section{Literature Cited}

Araújo, F. F. de. Disponibilização de fósforo, correção do solo, teores foliares e rendimento de milho após a incorporação de fosfatos e lodo de curtume natural e compostado. Acta Scientiarum. Agronomy, v.33, p.355-360, 2011. https://doi.org/10.4025/actasciagron.v33i2.1021

Brunes, A. P.; Oliveira, S. de; Lemes, E. S.; Tavares, L. C.; Gehling, V. M.; Dias, L. W.; Villela, F. A. Adubação boratada e produção de sementes de trigo. Ciência Rural, v.45, p.1572-1578, 2015 https://doi.org/10.1590/0103-8478cr20131676

Calonego, J. C.; Ocani, K.; Ocani, M.; Santos, C. H. dos. Adubação boratada foliar na cultura da soja. Colloquium Agrariae, v.6, p.20-26, 2010. https://doi.org/10.5747/ca.2010.v06.n2.a054

Cantarella, H.; Raij, B. van; Camargo, C. E. O. Cereais. In: Raij, B. van; Cantarella, H.; Quaggio, J. A.; Furlani, A. M. C. Recomendações de calagem e adubação para o Estado de São Paulo. Campinas: Instituto Agronômico de Campinas, 1997. 285p. Boletim Técnico, 100
Debnath, M. R.; Jahiruddin, M.; Rahman, M. M.; Haque, M. A. Determining optimum rate of B application for higher yield of wheat in old Brahmaputra floodplain soil. Journal of Bangladesh Agricultural University, v.9, p.205-210, 2011.

EMBRAPA - Empresa Brasileira de Pesquisa Agropecuária. Sistema brasileiro de classificação de solos. 3.ed. Brasília: Embrapa Informação Tecnológica, 2013.353p.

Fageria, N. K. Níveis adequados e tóxicos de boro na produção de arroz, feijão, milho, soja e trigo em solo de cerrado. Revista Brasileira de Engenharia Agrícola Ambiental, v.4, p.57-62, 2000. https://doi.org/10.1590/S1415-43662000000100011

Ferreira D. F. Sisvar: A computer statistical analysis system. Ciência e Agrotecnologia, v.35, p.1039-1042, 2011. https://doi.org/10.1590/ S1413-70542011000600001

Foloni, J. S. S.; Barbosa, A. de M.; Catuchi, T. A.; Calonego, J. C.; Tiritan, C. S.; Dominato, J. C.; Creste, J. E. Efeitos da gessagem e da adubação boratada sobre os componentes de produção da cultura do amendoim. Scientia Agraria Paranaensis, v.15, p.202-208, 2016. https://doi.org/10.18188/1983-1471/sap. v15n2p202-208

Galindo, F. S.; Teixeira Filho, M. C. M.; Buzetti, S.; Santini, J. M. K.; Alves, C. J.; Nogueira, L. M.; Ludkiewicz, M. G. Z.; Andreotti, M.; Bellotte, J. L. M. Corn yield and foliar diagnosis affected by nitrogen fertilization and inoculation with Azospirillum brasilense. Revista Brasileira de Ciência do Solo, v.40, p.1-18, 2016. https:// doi.org/10.1590/18069657rbcs20150364

Galindo, F. S.; Teixeira Filho, M. C. M.; Buzetti, S.; Santini, J. M. K.; Bellotte, J. L. M.; Ludkiewicz, M. G. Z.; Andreotti, M.; Silva, V. M.; Garcia, C. M. de P. Chemical soil attributes after wheat cropping under nitrogen fertilization and inoculation with Azospirillum brasilense. Semina: Ciências Agrárias, v.38, p.659-669, 2017a. https://doi.org/10.5433/1679-0359.2017v38n2p659

Galindo, F. S.; Teixeira Filho, M. C. M.; Tarsitano, M. A. A.; Buzetti, S.; Santini, J. M. K.; Ludkiewicz, M. G. Z.; Alves, C. J.; Arf, O. Economic analysis of corn inoculated with Azospirillum brasilense associated with nitrogen sources and doses. Semina: Ciências Agrárias, v.38, p.1749-1764, 2017b. https://doi.org/10.5433/16790359.2017v38n4p1749

Malavolta, E.; Vitti, G. C.; Oliveira, S. A. de; Avaliação do estado nutricional das plantas: Princípios e aplicações. 2.ed. Piracicaba: Potafos, 1997, 319p.

Mantovani, J. P. M.; Calonego, J. C.; Foloni, J. S. S. Adubação foliar de boro em diferentes estádios fenológicos da cultura do amendoim. Revista Ceres, v.60, p.270-278, 2013. https://doi. org/10.1590/S0034-737X2013000200017

Marini, N.; Tunes, L. M.; Silva, J. I.; Moraes, D. M. de; Olivo, F.; Cantos, A. A. Carboxim Tiram fungicide effect in wheat seeds physiological quality (Triticum aestivum L.). Revista Brasileira de Ciência Agrárias, v.6, p.17-22, 2011. https://doi.org/10.5039/ agraria.v6i1a737

Metwally, A. M.; El-Shazoly, R. M.; Hamada, A. M. Physiological responses to excess boron in wheat cultivars. European Journal of Biological Research, v.7, p.1-8, 2017.

Muhmood, A.; Javid, S.; Niaz, A.; Majeed, A.; Majeed, T.; Anwar, M. Effect of boron on seed germination, seedling vigor and wheat yield. Soil \& Environment, v.33, p.17-22, 2014. 
Raij, B. van; Andrade, J. C.; Cantarella, H.; Quaggio, J. A. Análise química para avaliação da fertilidade de solos tropicais. Campinas: Instituto Agronômico de Campinas, 2001. 285p.

Souza, H. A. de; Natale, W.; Rozane, D. E.; Hernandes, A.; Romualdo, L. M. Calagem e adubação boratada na produção de feijoeiro. Revista Ciência Agronômica, v.42, p.249-257, 2011. https://doi.org/10.1590/S1806-66902011000200001

Tahir, M.; Tanveer, A.; Shah, T. H.; Fiaz, N.; Wasaya, A. Yield response of wheat (Triticum aestivum L.) to boron application at different growth stages. Pakistan Journal of Life and Social Sciences, v.7, p.39-42, 2009.

Teixeira Filho, M. C. M.; Buzetti, S.; Andreotti, M.; Arf, O.; Benett, C. G. S. Doses, fontes e épocas de aplicação de nitrogênio em trigo irrigado em plantio direto. Pesquisa Agropecuária Brasileira, v.45, p.797-804, 2010. https://doi.org/10.1590/S0100204X2010000800004
Teixeira Filho, M. C. M.; Buzetti, S.; Andreotti, M.; Benett, C. G. S.; Arf, O.; Sá, M. E. de. Wheat nitrogen fertilization under no till on the low altitude Brazilian Cerrado. Journal of Plant Nutrition, v.37, p.1732-1748, 2014. https://doi.org/10.1080/01904167.2014.889150 Teixeira Filho, M. C. M.; Buzetti, S.; Arf, O.; Alvarez, R. de C. F.; Maeda, A. S.; Sá, M. E. de. Resposta de cultivares de trigo ao nitrogênio com e sem tratamento fúngico. Revista Brasileira de Ciências Agrárias, v.7, p.626-634, 2012. https://doi.org/10.5039/agraria.v7i4a2110

Theago, E. Q.; Buzetti, S.; Teixeira Filho, M. C. M.; Andreotti, M.; Megda, M. M.; Benett, C. G. S. Doses, fontes e épocas de aplicação de nitrogênio influenciando teores de clorofila e produtividade do trigo. Revista Brasileira de Ciência do Solo, v.38, p.1826-1835, 2014. https://doi.org/10.1590/S0100-06832014000600017

USDA - United States Department of Agriculture. Databases: Production, supply and distribution online. 2016. Available on: <http://apps.fas.usda.gov/psdonline/>. Access on: Dez. 2016. 